\title{
Biodegradable PPE Made of Pineapple Fiber Paper
}

\author{
Stephanie Graciela Wiryadinata ${ }^{1 *}$, Innamia Indriani ${ }^{2}$, Sabrina Ilma Sakina ${ }^{3}$ \\ ${ }^{1}$ Institut Teknologi Bandung, Indonesia \\ ${ }^{2}$ Institut Teknologi Bandung, Indonesia \\ ${ }^{3}$ Institut Teknologi Bandung, Indonesia \\ *Corresponding author.Email: stepgracielaw@students.itb.ac.id
}

\begin{abstract}
The 2020 pandemic has driven the use of Personal Protective Equipment (PPE) and therefore, increased the amount of waste. Paper-like surgical masks are made from polypropylene, which is a non-biodegradable material. An alternative material for medical grade PPE that is equal to polypropylene is crucial to reduce waste. Pineapple leaves are a potential alternative for polypropylene. Pineapple Leaf Fiber (PALF) is rich in cellulose, cost effective, eco-friendly and has good fiber strength. To create PPE out of PALF, the fibers must be processed into paper. However, PALF paper has not yet been used widely in the medical industry. This methodology research was divided into two stages. The first stage used a quantitative approach by comparing the results of the properties test of PALF paper with SNI (Standar Nasional Indonesia, the National Standard of Indonesia). The second stage used a qualitative approach, namely the PPE product design process that utilized PALF paper as the basic material. An explorative approach was used to design comfortable PPE. The pineapple fiber paper PPE product will be tested to determine its medical grade which is shown in paper resistance, air permeability/porosity, and water absorption level. The results of this PALF exploration are to open up opportunities for the use of PALF and expected to show a production-ready material for PPE.
\end{abstract}

Keywords: pineapple leaf fiber (PALF), personal protective equipment (PPE), biodegradable, disposable

\section{INTRODUCTION}

\subsection{Objective}

The COVID-19 pandemic has lasted for more than a year and caused a monumental shift in our everyday lives, especially the needs of disposable personal protective equipments. The COVID-19 pandemic waste is getting more significant and more disturbing. The WHO estimates 89 million medical masks are needed globally every month during the coronavirus pandemic last [1] [2]. Massively discarded disposable PPE containing viruses are dumped in cities and nature, which will cause environmental pollution, especially there was a massive increase of medical waste from between 40 and 50 tons per day [3]. The widespread use of PPE during the COVID-19 pandemic has caused much waste to take a long time, which takes 50 years to decompose due to polypropylene materials [4] [5]. One solution to reduce this waste is cloth masks, but the recommended masks are disposable medical masks covered with cloth masks.

Natural fibers have received increased attention recently due to concerns about environmental issues. Natural fibers offer various benefits such as renewable properties and excellent biodegradability that do not negatively affect the environment. Pineapple leaf fiber can be the alternative and widely cultivated that has high mass production potential [6]. Pineapple leaf fiber (PALF) is an alternative material used and part of natural fiber. Low density, good stiffness, high durability, rich in cellulose, cost-effectiveness, and good fiber strength and sustainability are the advantages of natural fibers that can be usedas an alternative material in various industries, one of which is the health industry.

With the advantages of pineapple fiber, research has been done on making paper from pineapple fiber (hand sheet paper making) [7]. PALF paper has not yet been used widely in the medical industry. From the PALF's characteristics, PALF paper can estimate that 
PALF has a great opportunity and potential to be developed towards the needs of the medical sector during this COVID-19 pandemic.

\subsection{Objective}

The main objective of this research is to provide an alternative solution or substitute to nonbiodegradable PPE. Based on the commonly known characteristics and abundance of availability, PALF hand sheets were chosen to be developed as the PPE material. This research also aimed to analyze the properties of PALF paper to ensure good quality, safety, and efficacy of the PPE based on WHO standards.

With this exploration research, the writer hopes to help to reduce PPE waste that comes from usage at home, in public, or in the health industry.

\subsection{Methodology}

This research was divided into two stages. The first stage used a quantitative approach by comparing the results of the properties test of PALF paper with SNI (Standar Nasional Indonesia, the National Standard of Indonesia). This stage is intended to obtain the characteristics of PALF paper to determine whether PALF paper can be used as medical-grade PPE.

The second stage used a qualitative approach, namely the PPE product design process that utilized PALF paper as the basic material. An explorative approach was used to design comfortable PPE. This method is a strategy to reduce non-biodegradable PPE. The simulated design is to be made from PALF paper, in accordance with the current PPE standard.

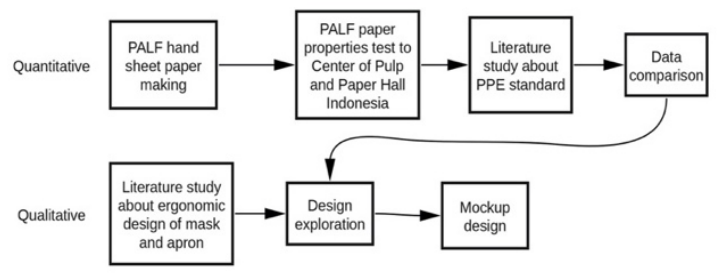

Figure 1. Methodology Research Flow Chart

\section{FINDINGS}

\subsection{PPE Data Standard}

The majority of data from WHO describes that PPE used must have durability, comfortable, liquid and stain resistant, and great breathability. Table 1 below is PPE data from WHO.

Table 1. PPE Standard from World Health Organization [1] [2] [3]

\begin{tabular}{|c|c|c|c|c|}
\hline No. & Type of PPE & Characteristics & Recommended use & $\begin{array}{c}\text { Performance standards (or } \\
\text { alternative equivalent) }\end{array}$ \\
\hline 1 & $\begin{array}{l}\text { Medical mask, } \\
\text { for health care } \\
\text { worker }\end{array}$ & $\begin{array}{l}\text { It is designed for single use [5] and } \\
\text { fits closely over the wearer's nose, } \\
\text { cheeks, and chin. Various } \\
\text { thicknesses, filtration, and fluid } \\
\text { resistance are the levels of mask } \\
\text { standard. [2] }\end{array}$ & $\begin{array}{l}\text { Use without removing } \\
\text { for up to } 6 \text { hours. }\end{array}$ & $\begin{array}{l}\text { EN14683 Type IIR, annex C } \\
\text { [6] [7] } \\
\text { ASTM F2100 Level 1, 2, or } 3 \\
\text { (120 mmHg) [8] } \\
\text { At least 98\% bacterial droplet } \\
\text { filtration standard or YY0469 } \\
\text { [2] } \\
\text { Or alternative equivalent } \\
\text { standard [2] }\end{array}$ \\
\hline 2 & $\begin{array}{l}\text { Medical mask, } \\
\text { for patient } \\
\text { (public use) }\end{array}$ & $\begin{array}{l}\text { Good breathability is essential to a } \\
\text { medical mask [5]. Also, internal and } \\
\text { external faces should be clearly } \\
\text { identified. Various thicknesses, }\end{array}$ & $\begin{array}{l}\text { Use without removing } \\
\text { for up to } 6 \text { hours [2]. }\end{array}$ & $\begin{array}{l}\text { EN } 14683 \text { Type I, annex C [6] } \\
\text { [7] }\end{array}$ \\
\hline
\end{tabular}




\begin{tabular}{|c|c|c|c|c|}
\hline No. & Type of PPE & Characteristics & Recommended use & $\begin{array}{l}\text { Performance standards (or } \\
\text { alternative equivalent) }\end{array}$ \\
\hline & & $\begin{array}{l}\text { filtration, and fluid resistance are the } \\
\text { levels of mask standard. [2] }\end{array}$ & & $\begin{array}{l}\text { YY } 0469 \text { or YY/T 0969, if } \\
\text { bacterial droplet filtration is } \\
\text { below } 98 \% \text { [2] } \\
\text { Or alternative equivalent } \\
\text { standard [2] }\end{array}$ \\
\hline 3 & $\begin{array}{l}\text { Apron, } \\
\text { disposable }\end{array}$ & $\begin{array}{l}\text { Single-use straight sleeveless } \\
\text { protective apron, for use in health } \\
\text { care settings. } \\
\text { Seamless liquid proof and stain } \\
\text { resistant, which can resist any kind } \\
\text { fluid, such as water and disinfectant } \\
\text { (ethanol ethanol } 70 \% \text { and chlorine } \\
\text { solution } 0,05 \% \text { or } 500 . \text { Ppm). [2] } \\
\text { Thickness of apron that can resist } \\
\text { water approximately not less than } \\
50 \mu m \\
\text { Polyethylene } \\
\text { (PE)/biodegradable/compostable } \\
\text { material are open to apron making. } \\
\text { Comfortable is main key to wear, } \\
\text { apron. Usually, apron has back-and } \\
\text { neck-band strips attached ( } 4 \text { in total) } \\
\text { can be adjusted. } \\
\text { The size is } 85 \times 145 \mathrm{~cm} \text { ( } \mathrm{w} \times \mathrm{I} \text { ) } \\
( \pm 15 \% \text { ) on white }\end{array}$ & $\begin{array}{l}\text { Plastic aprons do not } \\
\text { protect the arms and } \\
\text { the back of the torso } \\
\text { and provide less } \\
\text { coverage than gowns. } \\
\text { Apron should be } \\
\text { paired with lab coats or } \\
\text { patient gowns when } \\
\text { performing AGPs and } \\
\text { support treatments [2]. }\end{array}$ & $\begin{array}{l}\text { Product performance testing if } \\
\text { biodegradable } \\
\text { EN } 13432 \text { [9] [7] } \\
\text { ASTM D6400, ASTM D5034, } \\
\text { ASTM D1682. [2] } \\
\text { Or alternative equivalent set } \\
\text { of standards. [2] }\end{array}$ \\
\hline
\end{tabular}

\subsection{PALF Paper Test Results}

Table 2 below is processing PALF Paper results of Center of Pulp and Paper Hall (BBPK, Balai Besar
Pulp dan Kertas), Industrial Research and Development Agency. From these data, PALF paper has light weight, good strength, and high water content which means has high porosity. Table 1 and 2 will be compared in the next section (table 3 ).

Table 2. PALF Paper Test Results

\begin{tabular}{|l|l|l|l|l|}
\hline No. & \multicolumn{1}{|c|}{ Parameter } & Units & Test Results & \multicolumn{1}{c|}{ Method } \\
\hline 1 & Gram & $\mathrm{g} / \mathrm{m}^{2}$ & 100,8 & SNI ISO 536:2010 \\
\hline
\end{tabular}




\begin{tabular}{|l|l|l|l|l|}
\hline 2 & Water content & $\%$ & 7,5 & SNI ISO 287:2014 \\
\hline 3 & Thickness & $\mu \mathrm{m}$ & 381,5 & SNI ISO 534:2011 \\
\hline 4 & Tensile strength & $\mathrm{kN} / \mathrm{m}$ & 2,21 & SNI ISO 1924-2:2016 \\
\hline 5 & Gurley porosity & seconds/100mL & 1,4 & SNI ISO 5636-5:2011 \\
\hline 6 & Cobb-60 water absorption & $\mathrm{g} / \mathrm{m}^{2}$ & 590,9 & SNI ISO 535:2016 \\
\hline 7 & Wet pull resistance & $\mathrm{N} / \mathrm{m}$ & 266,6 & SNI 1306:2009 \\
\hline 8 & Ply bond & $\mathrm{J} / \mathrm{m}^{2}$ & 228,4 & SNI ISO 16260:2016 \\
\hline
\end{tabular}

Remarks : Condition of testing room : Temperature $23 \pm 1{ }^{\circ} \mathrm{C}$; $\mathrm{RH} 50 \pm 2 \%$

*) surface pressure of test equipment $100 \mathrm{kPa}$

*) A4 paper size with an average weight of 20 sheets of paper

\section{FINDINGS}

\subsection{Comparison Result}

The PALF paper has potential for PPE material in terms of texture, weight, thickness, tensile strength, wet pull resistance, and ply bond, but has disadvantages such as having high water content, good porosity, and high water absorption. These disadvantages contrast with standard PPE, which must be resistant to liquid. The primary standard of PPE material is ASTM Level 1, ASTM Level 2, dan ASTM Level 3 according to WHO's technical specifications of PPE [2]. The ASTM Level 1 is ideal for procedures with low fluid exposure risk (no splashes or sprays expected) [2]. The ASTM Level 2 is suitable for systems with a moderate risk of liquid exposure (a situation that can produce splashes or sprays) [2]. The ASTM Level 3 is ideal for procedures with a high risk of fluid exposure (a case will make splashes or sprays) [2]. On the one hand, various thicknesses and levels of fluid resistance and filtration are part of the medical mask's types. Therefore, PALF paper can still be used as PPE with the ASTM Level 1 procedure and a maximum of level 2, where the risk of exposure to liquids is low to moderate. Furthermore, from the disadvantages of PALF paper, remember that using PPE from pineapple fiber must be replaced frequently or immediately replaced when exposed to liquids to keep it safe.

The type of user category in COVID-19 on personal protective equipment is divided into 3, namely, levels 1, 2, and 3 [11]. Level 1 is intended for use by healthcare professionals. Level 2 is for professionals who are not working in the health field and are still exposed to many individuals. Level 3 is designed to promote group protection, use by individuals in public. The types of users who can use the PPE from the PALF paper from this research are level 2 and level 3.

As mentioned above, the $100 \%$ pineapple fiber paper can still be used as a primary material for PPE because it has advantages in texture, weight, thickness, tensile strength, wet pull resistance, and good ply bond. This material has an excellent internal strength of paper and board materials that is easy to shape according to the structure of the user's face (for masks) and body (for aprons). Moreover, the material is light and solid, does not wrinkle, and has low slip resistance, making the user more comfortable (not slippery material). Actually, from the lack of high water absorption, it can be utilized on the inside of the PPE, and it has been found that the airflow rate in PPE has the most significant effect. These disadvantages make PALF paper material suitable for sweatabsorbent and breathable material, which means this pineapple paper is body friendly.

The PPE of a mask made from pineapple paper is a surgical mask designed to be disposable, which usually has three layers [12]. This PALF paper of a mask can be used on the 2nd, 3rd, or both layers. Then, aprons from PALF paper can still be used because the primary purpose of the apron is so that the user is not exposed to liquids. Moreover, the procedure for using aprons still has to use lab coats or patient gowns. The advantages and disadvantages of PALF paper still make a tremendous potential biodegradable material for PPE. 
Table 3. Comparison of PALF Paper Test Results and PPE Standards

\begin{tabular}{|c|c|c|c|c|}
\hline No & Parameter & Measurement & PPE standards & Analysis \\
\hline \multicolumn{5}{|l|}{ Mask } \\
\hline 1 & Gram & $100,8 \mathrm{~g} / \mathrm{m} 2$ & $\begin{array}{l}\text { Comfortable and light while } \\
\text { using. Available in various } \\
\text { weights according to the } \\
\text { thickness. }\end{array}$ & $\begin{array}{l}\text { The PALF paper weight is light, so it is } \\
\text { convenient to use as mask. }\end{array}$ \\
\hline 2 & Water content & $7,5 \%$ & $\begin{array}{l}\text { Fluid resistance to ASTM } \\
\text { F2100 Level 1, 2, or } 3[7] \text {. }\end{array}$ & $\begin{array}{l}\text { The PALF paper has high water content, } \\
\text { can be used as level } 1 \& 2 \text {. Ideal for low } \\
\text { and moderate risk of fluid exposure }\end{array}$ \\
\hline 3 & Thickness & $381,5 \mathrm{~m}$ & $\begin{array}{l}\text { Available in different } \\
\text { thicknesses. }\end{array}$ & $\begin{array}{l}\text { Medical mask is available in different } \\
\text { thicknesses. }\end{array}$ \\
\hline 4 & $\begin{array}{l}\text { Tensile } \\
\text { strength }\end{array}$ & $2,21 \mathrm{kN} / \mathrm{m}$ & $\begin{array}{l}\text { Use without removing for up to } \\
6 \text { hours, internal and external } \\
\text { faces should be clearly } \\
\text { identified. }\end{array}$ & $\begin{array}{l}\text { The PALF paper does not wrinkle and has } \\
\text { excellent texture. }\end{array}$ \\
\hline 5 & $\begin{array}{l}\text { Gurley } \\
\text { porosity }\end{array}$ & $\begin{array}{l}1,4 \\
\text { seconds/100mL }\end{array}$ & $\begin{array}{l}\text { Good breathability, EN } 14683 \\
\text { Type I. }\end{array}$ & $\begin{array}{l}\text { The PALF paper has good absorption } \\
\text { porosity, but on the one hand, it just } \\
\text { absorbs right away. It must be } \\
\text { remembered that when exposed to liquid, } \\
\text { it must be replaced immediately because } \\
\text { one of the conditions for the mask is } \\
\text { waterproof, with this size it is still okay. In } \\
\text { addition, by having an absorbing speed, } \\
\text { porosity makes the mask breathable. }\end{array}$ \\
\hline 6 & $\begin{array}{l}\text { Cobb- } 60 \text { water } \\
\text { absorption }\end{array}$ & $590,9 \mathrm{~g} / \mathrm{m} 2$ & $\begin{array}{l}\text { Various levels of fluid- } \\
\text { resistance and filtration. }\end{array}$ & $\begin{array}{l}\text { The PALF paper has high water absorption } \\
\text { and can be used as sweat-absorbent. }\end{array}$ \\
\hline 7 & $\begin{array}{l}\text { Wet pull } \\
\text { resistance }\end{array}$ & $266,6 \mathrm{~N} / \mathrm{m}$ & $\begin{array}{l}\text { Comfortable and light while } \\
\text { using. Available in various } \\
\text { weights according to the } \\
\text { thickness. }\end{array}$ & $\begin{array}{l}\text { The PALF paper weight is light, so it is } \\
\text { convenient to use as mask. }\end{array}$ \\
\hline 8 & Ply bond & $228,4 \mathrm{~J} / \mathrm{m} 2[10]$ & $\begin{array}{l}\text { Fluid resistance to ASTM } \\
\text { F2100 Level 1, 2, or } 3 \text { [7]. }\end{array}$ & $\begin{array}{l}\text { The PALF paper has high water content, } \\
\text { can be used as level } 1 \& 2 \text {. Ideal for low } \\
\text { and moderate risk of fluid exposure }\end{array}$ \\
\hline 6 & $\begin{array}{l}\text { Cobb- } 60 \text { water } \\
\text { absorption }\end{array}$ & $590,9 \mathrm{~g} / \mathrm{m} 2$ & $\begin{array}{l}\text { Various levels of fluid- } \\
\text { resistance and filtration. }\end{array}$ & $\begin{array}{l}\text { The PALF paper has high water absorption } \\
\text { and can be used as sweat-absorbent. }\end{array}$ \\
\hline 7 & $\begin{array}{l}\text { Wet pull } \\
\text { resistance }\end{array}$ & $266,6 \mathrm{~N} / \mathrm{m}$ & $\begin{array}{l}\text { Comfortable and light while } \\
\text { using. Available in various } \\
\text { weights according to the } \\
\text { thickness. }\end{array}$ & $\begin{array}{l}\text { The PALF paper weight is light, so it is } \\
\text { convenient to use as mask. }\end{array}$ \\
\hline
\end{tabular}




\begin{tabular}{|c|c|c|c|c|}
\hline No & Parameter & Measurement & PPE standards & Analysis \\
\hline 8 & Ply bond & $228,4 \mathrm{~J} / \mathrm{m} 2[10]$ & $\begin{array}{l}\text { Fluid resistance to ASTM } \\
\text { F2100 Level } 1,2 \text {, or } 3[7] \text {. }\end{array}$ & $\begin{array}{l}\text { The PALF paper has high water content, } \\
\text { can be used as level } 1 \& 2 \text {. Ideal for low } \\
\text { and moderate risk of fluid exposure }\end{array}$ \\
\hline \multicolumn{5}{|c|}{ Apron } \\
\hline 1 & Gram & $100,8 \mathrm{~g} / \mathrm{m} 2$ & $\begin{array}{l}\text { Comfortable while using. } \\
\text { Minimum weight : } 300 \mathrm{~g} / \mathrm{m} 2\end{array}$ & $\begin{array}{l}\text { The PALF paper weight is light, so it is } \\
\text { convenient to use in size } 85 \times 145 \mathrm{~cm} \text { ( } \mathrm{x} \times \\
\text { I) ( } 15 \%) \text { [2]. The paper tested has an A4 } \\
\text { size }(21 \times 29.7 \mathrm{~cm} \text { ) which if made with a } \\
\text { standard size apron, its weight will exceed } \\
\text { the standard data. }\end{array}$ \\
\hline 2 & Water content & $7,5 \%$ & $\begin{array}{l}\text { Can resist water and } \\
\text { disinfectant (ethanol } 70 \% \text { and } \\
\text { chlorine solution } 0,05 \% \text { or } 500 \\
\text { Ppm) }\end{array}$ & $\begin{array}{l}\text { The PALF paper has high water content. } \\
\text { Apron should be changed into new one if it } \\
\text { becomes wet, damage, or exposed to } \\
\text { chemicals, infectious body fluids. }\end{array}$ \\
\hline 3 & Thickness & $381,5 \mathrm{~m}$ & Not less than $50 \mathrm{~m}$ & $\begin{array}{l}\text { The PALF paper has a great thickness, } \\
\text { exceeds the standard, has good } \\
\text { protection. }\end{array}$ \\
\hline 4 & $\begin{array}{l}\text { Tensile } \\
\text { strength }\end{array}$ & $2,21 \mathrm{kN} / \mathrm{m}$ & $\begin{array}{l}\text { The use without removal. } \\
\text { ASTM D5034, ASTM D1682. } \\
\text { [8] }\end{array}$ & $\begin{array}{l}\text { The PALF paper does not wrinkle and easy } \\
\text { shape for PPE aprons that have back-and } \\
\text { neck-band strips attached. }\end{array}$ \\
\hline 5 & $\begin{array}{l}\text { Gurley } \\
\text { porosity }\end{array}$ & $\begin{array}{l}1,4 \\
\text { seconds } / 100 \mathrm{~mL}\end{array}$ & $\begin{array}{l}\text { Seamless liquid proof and } \\
\text { stain resistant. }\end{array}$ & $\begin{array}{l}\text { The PALF paper has good porosity. Apron } \\
\text { should be changed into new one if it } \\
\text { becomes wet, damaged, or exposed to a } \\
\text { splash of chemicals, infectious body fluids. }\end{array}$ \\
\hline 6 & $\begin{array}{l}\text { Cobb- } 60 \text { water } \\
\text { absorption }\end{array}$ & $590,9 \mathrm{~g} / \mathrm{m} 2$ & $\begin{array}{l}\text { Seamless liquid proof and } \\
\text { stain resistant. }\end{array}$ & $\begin{array}{l}\text { The PALF paper has high water } \\
\text { absorption. Urgently need to be changed if } \\
\text { it becomes wet, damaged, or exposed to a } \\
\text { splash of chemicals, infectious body fluids. }\end{array}$ \\
\hline 7 & $\begin{array}{l}\text { Wet pull } \\
\text { resistance }\end{array}$ & $266,6 \mathrm{~N} / \mathrm{m}$ & $\begin{array}{l}\text { The use without removal, } \\
\text { standard EN13432 plastic }\end{array}$ & $\begin{array}{l}\text { The PALF paper has low slip resistance } \\
\text { potential which makes apron more } \\
\text { comfortable than the plastic one but still } \\
\text { has good protection. }\end{array}$ \\
\hline 8 & Ply bond & $228,4 \mathrm{~J} / \mathrm{m} 2$ [10] & $\begin{array}{l}\text { The use without removal, } \\
\text { standard EN13432 plastic }\end{array}$ & $\begin{array}{l}\text { The PALF paper has great internal } \\
\text { strength of paper and board materials, } \\
\text { easy to shape into a PPE apron that } \\
\text { conforms to the shape of the user body. }\end{array}$ \\
\hline
\end{tabular}

\subsection{PPE Design Prototype}

The mask standard should completely cover the nose and mouth, have a nose wire to prevent air from leaking out of the top of the mask. Standard medical masks are composed of 3 layers of synthetic nonwoven materials; the outer layer, filter layer, and inner layer. The outer layer protects against liquid 
splashes, the filter layer is a virus barrier, and the inner layer absorbs moisture released by the wearer.

The manufacture of pineapple fiber masks is the same as standard medical masks. It is usually using a medical mask machine (TM120 Semi-automatic Medical Mask Making Machine or TM100 Automatic Medical Mask Production Line) [12] so that only the material is changed to PALF paper. Overall, making masks using a laminator machine by combining three layers of masks, but in this section, it must be remembered that the material comes from natural fibers that are flammable, the compression process should not be too hot and rely more on folding and flattening steps. Then, stick wire for a structure that fits closely over the wearer's nose, cheeks, and chin into a laminated three-layer mask. The mask will be folded using a folding device and will be flattened by a roller machine. Then, strengthen the edges of the mask, fix the hanging ear rope with the thermoforming device. Lastly is disinfection.

In Figure 2, there is a prototype mask design from pineapple fiber paper. The mask design follows the standard because it is the most ergonomic to use and has internal and external faces that should be identified, including the wearer's nose, cheeks, and chin. From Figure 2 (a), the color of the mask will be yellowish-white because the color is entirely derived from pineapple fiber. Following the analysis, in Figure 2, PALF paper is used as a filter and inner layer, or only the inner layer because it has high water absorption.

Then, in Figure 3, a prototype of the PALF paper apron has various looks. The essential element of the PPE apron is that it is comfortable to wear and protects the wearer from direct liquids. PALF paper can be directly used and formed into an apron with an $85 \mathrm{x}$ $145 \mathrm{~cm}$ (w x 1) apron body size. The design of the apron follows the WHO standard, which has adjusted back-and neck-band strips attached (four in total). The color of the apron is also yellowish-white because the color comes from pineapple fiber.

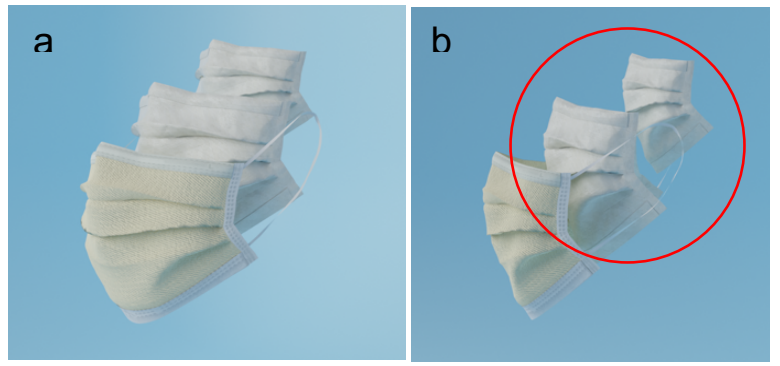

Figure 2. (a) PALF Paper Mask Prototype; (b) Inner Layers PALF Paper Mask Prototype

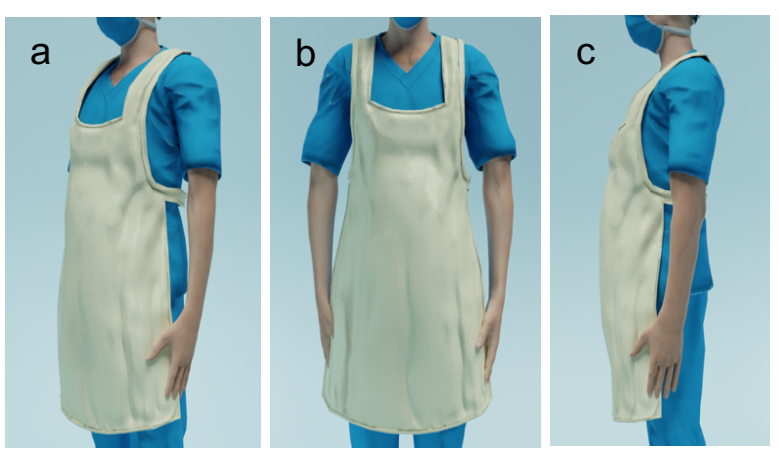

Figure 3. (a) PALF Paper Apron Prototype; (b) Inner Layers PALF Paper Apron Prototype

\section{CONCLUSION}

This research focuses on using PALF paper to be used as PPE, and the results of the PALF paper test are compared with standard PPE data from World Health Organization so that they know the potential of PALF paper. The analysis results show that PALF paper has advantages in texture, weight, thickness, tensile strength, wet pull resistance, and good ply bond. These advantages made it easy to shape according to the structure of the user's face (for masks) and body (for aprons). Moreover, light and solid characteristics do not wrinkle and have low slip resistance, making the user more comfortable using it (not slippery material). The airflow rate has the most significant effect on the PPE standard, so this is why PALF paper has high water content, porosity, and water absorption capacity, where these characteristics contrast with fluid resistance. Even though PALF paper has disadvantages, this disadvantage can be turned into the advantages of being a sweat absorber.

The types of users who can use the PPE from the PALF paper from this research are level 2 and level 3. For the ASTM levels, PALF paper can still be used as PPE with the ASTM Level 1 procedure and a maximum of level 2, where the risk of exposure to liquids is low to moderate. From this PALF paper level, it should be remembered that PPE PALF paper must be replaced frequently or immediately replaced when exposed to liquids to keep it safe.

The mask prototype is the best if PALF paper is used as the mask's inner layer or filter layer because of the advantage of absorbent materials. For the apron prototype, the PALF paper apron already has good protection standards as PPE. Aprons should still be paired with lab coats or patient gowns because it does not protect the arms and the torso, with less coverage. Based on testing and discussion results, pineapple fiber can be used as an alternative in PPE. PALF 
paper, which can be used as an alternative, means producing something new for the textile design field is brought to the health industry. It already exists, but the use of PALF paper is highlighted in this research. Furthermore, using paper from PALF provides more benefits to waste sources from the pineapple plantation in Indonesia and provide new opportunities for its use.

\section{SUGGESTION}

For further research, it is better to make PALF paper pulp mixed with a biodegradable polymer to reduce water absorption for the best result. The biodegradable polymer is mixed into the pineapple fiber pulp, and the hand sheet paper making remains the same. The outermost layer is recommended to use a biodegradable polymer to protect the user from liquids, especially the use of the outer layer is for protection against liquid splashes. In addition, can resist liquid is one of the PPE standards. Especially in the production section using heat, it is better to have a layer made from biodegradable polymer to reduce the risk of the material being burned. The biodegradable polymer is also a heat protectant for pineapple material when processed into PPE and as an adhesive.

The data that has been tested is sufficient, but the results of the paper test can be added with Bacterial Filtration Efficiency (BFE) to ensure further the effectiveness of masks made from PALF paper. The BFE test results are within the efficiency parameters in the use of PPE. This test is recommended in order to get better PPE results.

\section{ACKNOWLEDGMENTS}

This research was funded by the 2021 PPMI grant from Institut Teknologi Bandung, and is an output of the Craft and Tradition Research Group.

\section{REFERENCES}

[1] S. S., Face mask and medical waste disposal during the novel COVID-19 pandemic in Asia, Case studies in chemical and environmental engineering, November 2020.

[2] World Health Organization, Technical specifications of personal protective equipment for COVID-19, 13 November 2020. [Online]. Available: https://www.who.int/teams/healthproduct-and-policy-standards/assistive-andmedical-technology/medical-devices/ppe/ppecovid. [Accessed 7 June 2021].
[3] World Health Organization, Rational use of personal protective equipment for coronavirus disease (COVID-19) and considerations during severe shortages," 23 December 2020. [Online]. Available:

https://www.who.int/publications/i/item/rational -use-of-personal-protective-equipment-forcoronavirus-disease-(covid-19)-andconsiderations-during-severe-shortages. [Accessed 7 June 2021].

[4] World Health Organization, Advice on the use of masks in the context of COVID-19," 5 June 2020. [Online]. Available: https://apps.who.int/iris/bitstream/handle/10665/ 332293/WHO-2019-nCov-IPC_Masks-2020.4eng.pdf? sequence $=1 \&$ isAllowed $=y$. [Accessed 8 June 2021].

[5] J. T. J. Ju, L. N. Boisvert, Y. Y. Zuo, Face masks against COVID-19 : standards, efficacy, testing and decontamination methods," Elsevier, vol. 292, no. 102435, p. 5, 2021.

[6] NBN, Medical face masks - requirements and test methods, 28 August 2019. [Online]. Available: https://www.edana.org/docs/defaultsource/international-standards/nbn-en14683_2019-ac2019_e.pdf?sfvrsn=3797c92b_4. [Accessed 5 July 2021].

[7] World Health Organization, Webinar on personal protective equipment production, 4 May 2020. [Online]. Available: https://www.ifc.org/wps/wcm/connect/8d19623 e-8b4e-46bc-b12abb68b7d9ecd3/Presentation+by+WHO.pdf?MO $\mathrm{D}=\mathrm{AJPERES} \& \mathrm{CVID}=\mathrm{n} 85 \mathrm{udMl}$. [Accessed 7 July 2021].

[8] Kansas : Department of Health and Environment, Understanding ASTM levels for facemasks, 7 July 2020. [Online]. Available: https://www.coronavirus.kdheks.gov/Document Center/View/1416/Understanding-ASTMLevels-for-Facemasks-PDF---7-30-20 [Accessed 5 July 2021].

[9] European Bioplastics, EN 13432 CERTIFIED BIOPLASTICS PERFORMANCE IN INDUSTRIAL COMPOSTING, April 2015. [Online]. Available: https://docs.europeanbioplastics.org/publications/bp/EUBP_BP_En_1 3432.pdf. [Accessed 5 July 2021]. 
[10] Health and Safety Authority, Measuring slip resistance, [Online]. Available: https://www.hsa.ie/eng/Topics/Slips_Trips_Fall s/Pedestrian_Surfaces/Measuring_Slip_Resistan ce/Measuring_Slip_Resistance.html. [Accessed 8 July 2021].

[11] R. Fangueiro, D. P. Ferreira, P. Silva, C. Silva, Protective masks, Portugal: Fibrenamics, 2020.

[12] Testex, Medical face mask machine: the complete guide for the medical masks production, 17 February 2020. [Online]. Available:

https://www.testextextile.com/fighting-thecoronavirus-top-6-knowledge-to-know-beforeinvesting-in-establishing-disposable-medicalmask-production-lines/. [Accessed 1 July 2021].

[13] World Health Organization, Shortage of personal protective equipment endangering health workers worldwide, 3 March 2020. [Online]. Available: https:/www.who.int/news/item/0303-2020-shortage-of-personal-protectiveequipment-endangering-health-workersworldwide. [Accessed 1 June 2021].

[14] R. Deer, The growing waste \& recycling problems from PPE, masks, and COVID-19, 24 March 2021. [Online]. Available: https://www.roadrunnerwm.com/blog/impactof-ppe-waste. [Accessed 9 April 2021].

[15] C. Fletcher, What happens to waste PPE during the coronavirus pandemic?, 12 May 2020. [Online]. Available: https://heconversation.com/what-happens-towaste-ppe-during-the-coronavirus-pandemic137632. [Accessed 9 April 2021].

[16] Y. Thirumal, Advantages of pineapple fiber, July 2010. [Online]. Available: https://www.fibre2fashion.com/industryarticle/5076/advantages-of-pineapple-fiber. [Accessed 9 April 2021].

[17] A. R. Jiniputri, S. I. Sakina, A. Oktaviana, Exploration of natural fiber processing of smooth cayenne variety pineapple leaves with pulping and paper making techniques, in Balai Besar Tekstil, Bandung, 2020.

[18] T. M. Adyel, Accumulation of plastic waste during COVID-19, AAAS (American Association for the Advancement of Science), vol. 369, no. 6509, pp. 1314-1315, 11 September 2020.
[19] S. You, C. Sonne, Y. S. Ok, COVID-19's unsustainable waste management, $A A A S$ (American Association for the Advancement of Science), vol. 368, no. 6498, p. 1438, 2020

[20] Itsrur, Sedikit banyak tentang material APD dalam penanganan Covid-19, Institut Teknologi Sepuluh Nopember, 6 May 2020. [Online]. Available:

https://www.its.ac.id/news/2020/05/06/sedikitbanyak-tentang-material-apd-dalampenanganan-covid-19/. [Accessed 8 March 2021]. 